\title{
PERJANJIAN KREDIT PERBANKAN KONVENSIONAL DAN AKAD PEMBIAYAAN PERBANKAN SYARIAH : SUATU TINJAUAN DESKRIPTIF DALAM HUKUM DI INDONESIA
}

\author{
Miftah Idris \\ Fakultas Hukum \\ Universitas Muhammadiyah Luwuk Banggai \\ E-mail : miftah.idris@mail.ugm.ac.id
}

\begin{abstract}
ABSTRAK
Di dalam penyaluran dana, sistem yang dianut perbankan konvensional maupun perbankan syariah hampir sama dalam menyalurkan dananya baik itu dengan pemberian kredit maupun pemberian pembiayaan oleh bank kepada nasabahnya. Namun secara spesifik ada landasan hukum perjanjian atau akad yang membedakannya dimana jika perbankan konvensional lebih berlandaskan pada hukum perjanjian dalam KUHPerdata sedangkan dalam perbankan syariah lebih berlandaskan pada hukum akad yang diatur dalam syariat Islam (hukum Islam). Masalah yang dikaji dalam tulisan adalah bagaimana sebenarnya perjanjian kredit dalam perbankan konvensional dan bagaimana akad pembiayaan dalam perbankan syariah. Untuk mengetahui permasalahan tersebut maka akan digunakan jenis penelitian deskriptif dengan menggunakan jenis data sekunder sebagai sumber data dari tulisan ini dan kemudian dianalisis secara kualitatif. Sehingga didapat kesimpulan bahwa dalam Perjanjian Kredit adalah suatu proses awal antara kreditor dan debitor yang diterapkan dalam sistem perbankan konvensional dalam upayanya untuk mengembangkan dana yang telah dihimpunnya dan juga untuk dimanfaatkan dananya dengan sebaik-baiknya. Menurut asasnya perjanjian tersebut menganut sistem terbuka yang mengandung asas kebebasan membuat perjanjian, dan menurut bentuknya perjanjian kredit dalam perbankan konvensional ada yang dibuat di bawah tangan dan ada pula dibuat di hadapan notaris sedangkan akad pembiayaan dalam perbankan syariah juga adalah proses awal untuk pengembangan dana, namun akad pembiayaan perbankan syariah menganut sistem bagi untung dan rugi (Profit and Loss Sharing). Konsep kebersamaan dalam menghadapi risiko dan memperoleh keuntungan, serta adanya keadilan dalam berusaha adalah prinsip dasar dari sistem perbankan syariah. Sehingga penulis menyarankan idealnya baik pemberian pinjaman uang melalui kredit yang dianut dalam sistem perbankan konvensional maupun pemberian pembiayaan yang dianut dalam sistem perbankan syariah kepada debitor dan mudharib sejatinya adalah bertujuan satu yaitu untuk membantu mensejahterahkan masyarakat secara adil dan merata.
\end{abstract}

Keywords: Perjanjian, Kredit, Pembiayaan, Perbankan Konvensiona, Syariah.

\section{ABSTRACT}

In distribution of fund, the system adopted by conventional banking and Islamic banking is almost the same in distributing the fund with the provision of credit and of financing by banks to their customers. There is specifically legal basis of contract (aqad) that distinguishes where conventional banking is based on the contract law in 
Burgerlijk Wetboek and Islamic banking is based on aqad law stipulated in Islamic Sharia (Islamic Law). Problems studied in this research is how the credit contract in the conventional banking and how aqad financing in islamic banking are actually. To know the problem, it will be used descriptive study using secondary data as the data source of this research and then analyzed qualitatively. Thus concluded that the credit contract is a beginning process between the creditor and debtor which are applied in the conventional banking system in its efforts to develop funds collected and also to utilize the funds with the best. But Islamic banking financing adheresses to the profit and loss sharing system that has a unity concept in facing of risk and benefit and also existed justice in bussiness is the basic principle of Islamic banking system. Advice author, ideally lending money through credit in conventional banking and financing in Islamic banking to debtor (mudharib) is truely one aiming to help communities prosper in a fair and equitable.

Keywords: contract, credit, financing, conventional banking, and sharia.

\section{Pendahuluan}

Aktivitas yang paling utama lembaga perbankan baik itu konvensional maupun syariah (bank Islam) adalah menghimpun dana dan menyalurkan dananya dalam bentuk perkreditan atau pembiayaan kepada masyarakat (Ikatan Bankir Indonesia, 2014). Pengistilah kredit banyak dipakai dalam sistem perbankan konvensional yang berbasis pada bunga (interest based), sedangkan dalam hukum perbankan syariah lebih dikenal dengan istilah pembiayaan (financing) yang berbasis pada keuntungan riil yang dikehendaki (margin) ataupun bagi hasil (profit sharing) (Ghofur;2007).

Secara prinsip, dua bank ini dibedakan dengan satu hal yaitu sistem bunga. Di mana perbankan konvensional menerapkan sistem bunga sedangkan perbankan syariah tidak sama sekali menerapkan sistem bunga melainkan sistem bagi hasil. Hal ini tidak lepas dari hukum dasar yang dianut dalam pembentukan perbankan syariah yaitu penerapan hukum Islam, di mana tidak diperbolehkan menerapkan yang namanya bunga yang menurut pendapat sebagian besar dari para ulama bahwa bunga itu adalah haram hukumnya di dalam Islam.

Di dalam menyalurkan dananya, dalam bentuk kredit maupun pembiayaan, bank pada umumnya hampir sama dalam pelaksanaan perjanjiannya ('aqad/contract/akad) yaitu dengan melihat beberapa pertimbangan dengan menerapkan asas kehati-hatian dalam pelaksanaannya. Hal ini menjadi poin penting dalam suatu perjanjian yang diterapkan oleh bank, agar baik bank maupun nasabah bisa menjadi saling menguntungkan satu sama lain setelah pemberian kredit dan pembiayaan nantinya.

Perjanjian dalam pemberian kredit dan pembiayaan yang dilakukan bank adalah hal yang paling penting untuk diperhatikan oleh bank maupun nasabah, karena hal inilah tahap awal bagi bank dan nasabah dalam melaksanakan suatu perjanjian yang telah disepakatinya nanti.

Di dalam proses, pemberian kredit yang di lakukan oleh bank konvensional dalam menghimpun dana dengan mengeluarkan kredit 
kepada debitor. Agar dana yang dihimpunnya dapat berkembang pesat, bank konvensional menawarkan bunga yang menarik kepada debitor, dalam artian yang rendah. Agar debitor dapat mempergiat usahanya yang pada gilirannya dapat memacu pertumbuhan ekonomi. Sebab tingkat bunga kredit yang tinggi bisa menyebabkan produktivitas masyarakat sebagai debitor akan macet dan calon debitor juga akan enggan untuk melakukan pinjaman kredit ke bank jika bunga yang diberikan sangat tinggi.

Di satu sisi jika calon debitor enggan untuk melakukan pinjaman, maka proses penyaluran dana yang diterapkan untuk meraup keuntungan lewat bunga dalam bank konvensional tidak akan berjalan yang dampaknya akan membuat bank tersebut akan mengalami kerugian (Wibowo;2005), Sehingga istilah ini sering disebut dengan simbiosis mutualis (Tim Prima Pena;2006) (saling hidup-menghidupi satu sama lain).

Berbeda dengan bank syariah yang tidak menggunaan bunga melainkan menggunakan sistem keuntungan dan rugi (profit and loss sharing) maksudnya adalah memiliki konsep kebersamaan dalam menghadapi resiko rugi dan memperoleh keuntungan.

Dalam melakukan perjanjian kredit untuk meminjam modal, bank konvensional lebih melihat dari apa yang menjadi pinjaman yaitu utang pokok ditambah bunga, jadi peminjaman modal atau kredit ini tidak terlepas dari metode bunga yang merupakan sumber utama dari pendapatan bank konvensional, sedangkan pada bank syariah dalam menyalurkan dana atau pembiayaan menggunakan metode bagi hasil yang disepakati satu sama lain (ijab qabul) antara bank dan nasabah yang telah sesuai dengan fatwa Dewan Syariah Nasional (DSN).

Proporsi bagi hasil didasarkan atas jumlah keuntungan usaha yang diperoleh debitur, di mana pada bank syariah tidak ditentukan keuntungan pasti yang diterapkan pada awal perjanjian, yang berbeda dengan bank konvensional yang sudah memastikan keuntungannya dengan jumlah bunga yang diberikan kepada debitor, namun pada bank syariah keuntungan di muka hanya dimungkinkan untuk akad-akad (perjanjian) jual-beli melalui pembiayaan kepemilkan barang.

Baik bank konvensional maupun bank syariah adalah dua jenis bank yang memiliki kesamaan dan perbedaan dalam perjanjian kredit dan akad pembiayaan yang prinsipil, dan hal inilah yang membuat penulis akan mengkaji hal tersebut. Berawal dari uraian latar belakang tersebut sehingga didapat akar masalah yang diformulasikan dalam rumusan masalah sebagai berikut:

1. Bagaimana Perjanjian Kredit dalam Perbankan Konvensional?

2. Bagaimana Akad Pembiayaan dalam Perbankan Syariah?

\section{Metode Penelitian \\ Jenis Penelitian}

Jenis penelitian yang digunakan adalah Penelitian Deskriptif yaitu memberikan gambaran perjanjian kredit yang ada dalam perbankan konvensional dan akad pembiayaan yang ada dalam perbankan syariah, sehingga akan didapatkan penjelasan 
secara luas mengenai pembahasan yang dikaji.

\section{Jenis Data}

Jenis data yang digunakan adalah jenis data sekunder dimana data yang dihasilkan dari penelitian ini adalah data pustaka atau data sekunder. Untuk memperoleh data sekunder ini penulis melakukan penelusuran terhadap bahan hukum primer, sekunder dan tertier.

\section{Teknik Penyelesaian Masalah}

Setelah mendapatkan data yang terkait penelitian ini maka kemudian data akan dianalisis dengan beberapa cara untuk mendapatkan hasil penelitian yang kualitatif nantinya. Cara yang umum digunakan yaitu data diklasifikasikan kemudian data tersebut disistematisasikan lalu kemudian diinterpretasikan. Setelah proses tersebut dilalui, maka yang terakhir data tersebut akan kembali dievaluasi untuk mendukung penyelesaian suatu masalah dalam penelitian (Soekanto;2006).

\section{Hasil Penelitian dan Pembahasan Pengertian \\ Perjanjian atau Akad}

Charles Fried mengatakan "in Contract as Promise, the basis of contract is promise and contract law is 'built on' the enforcement of promises". Bahwa dia mengkarakteristikkan perjanjian sebagai sumpah, dan dasar dari perjanjian itu sendiri adalah sumpah dan hukum perjanjian (contract law) yang dibangun untuk penegakan hukum itu sendiri adalah sumpah.

Perjanjian secara etimologi adalah ikatan, sedangkan secara terminology perjanjian adalah suatu perbuatan dimana seseorang mengikatkan dirinya kepada seorang atau beberapa lain Brian;6).
Perjanjian atau juga disebut persetujuan sebagaimana dimaksud dalam Pasal 1313 KUHPerdata "suatu persetujuan adalah suatu perbuatan dimana satu orang atau lebih mengikatkan diri terhadap satu orang lain atau lebih" dan Pasal 1314 KUHPerdata yaitu "suatu persetujuan diadakan dengan cuma-cuma atau dengan memberatkan. Suatu persetujuan Cuma-Cuma adalah suatu persetujuan, bahwa pihak yang satu akan memberikan suatu keuntungan kepada pihak yang lain tanpa menerima imbalan. Suatu persetujuan memberatkan adalah suatu persetujuan yang mewajibkan tiap pihak untuk memberikan sesuatu, melakukan sesuatu atau tidak melakukan sesuatu.".

Maksud dari kutipan dalam pasal tersebut adalah suatu peristiwa di mana dua orang atau pihak saling berjanji untuk melakukan suatu hal atau suatu persetujuan yang dibuat oleh dua pihak atau lebih, masingmasing bersepakat akan menaati apa yang disebut dalam persetujuan itu.

Menurut pakar hukum Wirjono Prodjodikoro bahwa perjanjian adalah suatu hubungan hukum mengenai harta benda kekayaan antara dua pihak, di mana satu pihak berjanji atau dianggap berjanji untuk melakukan suatu hal atau untuk tidak melakukan suatu hal, sedang pihak lain berhak menuntut pelaksanaan janji itu (Prodjodikoro;1991).

Berbeda dengan hal tersebut, di dalam hukum Islam (syariah) kata perjanjian berasal dari kata 'aqad (selanjutnya disebut akad) yang secara etimologi bisa berarti "menyimpulkan" (Yunus;1990) sebagaimana yang di maksud dalam kamus Arab-Indonesia, namun dari sumber yang lain akad bisa berarti 
ikatan, sambungan ataupun janji. Ikatan jika bermakna ikatan antara ujung sesuatu (dua perkara), baik ikatan secara nyata maupun ikatan secara abstrak, dari satu sisi atau dari dua sisi (Firdaus;2005).

Menurut M. Hasbi AshShiddieqy dan Hendi Suhendi bahwa akad, secara bahasa adalah mengikat, yaitu mengumpulkan dua ujung tali dan mengikat salah satunya dengan yang lain, sehingga bersambung, kemudian keduanya menjadi satu (Suhendi;2007), sedangkan akad yang bermakna sambungan yaitu sambungan yang memegang kedua tepi itu dan mengikatnya. Dan akad yang secara etimologi bermakna janji sebagaimana yang dijelaskan di dalam al-Qur'an yaitu :

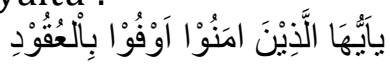

"Hai orang-orang yang beriman, penuhilah janji-janjimu." Di dalam ayat inilah yang menjadi hukum dasar bagi umat Islam yang ada di dalam kitab suci al-Qur'an dan juga hukum dasar dalam membuat hukum mengenai segala macam akad yang ada di dalam perbankan syariah dan juga kegiatan-kegiatan yang berkaitan dengan hubungan antara manusia dengan manusia yang lain.

Secara epistemologi atau istilah menurut hukum Islam, akad ialah sesuatu yang dengannya akan sempurna perpaduan antara dua macam kehendak, baik dengan kata atau yang lain, dan kemudian karenanya timbul ketentuan atau kepastian pada dua sisinya (Kuzari, 1995).

Menurut Abdul Aziz Muhammad kata akad dalam istilah bahasa berarti ikatan dan tali pengikat. Dari sinilah kemudian makna akad diterjemahkan secara bahasa sebagai: "menghubungkan antara dua perkataan, masuk juga di dalamnya janji dan sumpah, karena sumpah menguatkan niat berjanji untuk melaksanakanya isi sumpah atau meninggalkanya. Demikan juga halnya dengan janji sebagai perekat hubungan antara kedua belah pihak yang berjanji dan menguatkannya" (Azzam, 2010).

Perjanjian juga kadang didefinisikan sebagai hubungan. Karena merupakan suatu hubungan, maka suatu akad dapat timbul karena perjanjian, yakni dua pihak saling mengemukakan janjinya mengenai prestasi (http://al-azizimronrosadi.blogspot.com). Sebab perjanjian adalah semata-mata suatu persetujuan yang diakui oleh hukum. Persetujuan ini merupaka kepentingan yang pokok dalam dunia usaha, dan menjadi dasar dari kebanyakan transaksi dagang, seperti jual beli barang, tanah, pemberian kredit, asuransi, pengangkutan barang, pembentukan organisasi usaha, dan begitu jauh menyangkut juga tenaga kerja (Soulsby, 2013).

Dengan demikian definisi baik dari kalangan ahli hukum perdata dan ahli hukum Islam ada persamaan dimana titik temunya adalah kesepakatan untuk mengikatkan diri dengan seorang lainnya. Sehingga dari kesepakatan tersebut terdapat persetujuan atas beban yang mewajibkan masing-masing memberikan sesuatu, berbuat sesuatu ataupun tidak berbuat sesuatu.

\section{Perbankan Konvensional dan Syariah}

Pengertian

Perbankan Konvensional dan Perbankan Syariah adalah segala sesuatu yang menyangkut tentang bank baik Bank Konvensional maupun Bank Syariah, 
mencakup kelembagaan, kegiatan usaha, serta cara dan proses dalam melaksanakan kegiatan usahanya. Pendefinisian mengenai perbankan baik Bank Konvensional dan Bank Syariah tidaklah berbeda yang dijelaskan di dalam Undang-Undang Perbankan dan Undang-Undang Perbankan Syariah.

Ketika dijelaskan secara umum mengenai bank, Bank adalah badan usaha yang menghimpun dana dari masyarakat dalam bentuk simpanan dan menyalurkannya kepada masyarakat dalam bentuk kredit, pembiayaan dan atau bentuk-bentuk lainnya dalam rangka meningkatkan taraf hidup rakyat banyak. Pengentian ini juga berlaku untuk bank konvensional maupun bank syariah.

Namun pengertian secara khusus di mana Bank Konvensional yaitu bank yang aktifitasnya, baik penghimpunan dan penyaluran dana, memberikan dan mengenakan imbalan berupa bunga atau sejumlah imbalan dalam persentase tertentu dari dana untuk suatu periode tertentu. Persentse tertentu ini biasanya diterapka pertahun (Budisantoso, 2006).

Berbeda dengan Bank Konvensional, Bank Syariah adalah bank yang menjalankan kegiatan usahanya berdasarkan prinsip syariah dengan tidak menggunakan sistem bunga melainkan bagi hasil.

Perlu diketahui bahwa baik perbankan konvensional maupun perbankan syariah yaitu sebagai penghimpun dana dari masyarakat dalam bentuk simpanan dan menyalurkannya kepada masyarakat dalam bentuk kredit, maupun pembiayaan dan atau dalam bentuk lainnya dalam rangka meningkatkan taraf hidup masyarakat.

\section{Perjanjian Kredit Dalam Perbankan Konvensional}
Di
dalam
Perbankan

Konvensional dalam memaksimalkan perolehan dana dari masyarakat berupa menawarkan tingkat bunga simpanan yang menarik dari nasabah penyimpan dana, yaitu bunga setinggi-tingginya. Bunga simpanan dikatakan menarik jika lebih tinggi dari pada tingkat inflasi, tingkat bunga riil di luar negeri, dan tingkat bunga bank-bank dalam negeri lainnya.

Sebaliknya, bank konvensional dalam upayanya untuk mengembangkan dana yang telah dihimpunnya mengeluarkan kredit kepada debitor. Agar dana yang dihimpunnya dapat berkembang pesat, bank konvensional menawarkan bunga kredit yang menarik kepada debitor, dengan serendah-rendahnya, bahkan kalau bisa lebih rendah dari bunga simpanan.

Bunga kredit yang rendah dapat membuat pengusaha mempergiat usahanya yang pada gilirannya dapat memacu pertumbuhan ekonomi. Jika tidak, dengan tingkat bunga kredit yang tinggi dapat menyebabkan produkifitas masyarakat macet karena pengusaha kekurangan modal (Hendy, 2005).

Di dalam KUHPerdata mengatur perjanjian khusus, namun tidak satupun mengatur tentang perjanjian kredit. Oleh karena itu penetapan mengenai bentuk hubungan hukum antara Bank dan Nasabahnya, yang disebut dengan Perjanjian Kredit Bank itu sebenarnya harus digali dari sumber-sumber di luar KUHPerdata. 
Dalam hal ini Marhainis telah memperbandingkan kelima belas perjanjian khusus yang diatur dalam KUHPerdata dan menurutnya yang paling mendekati dengan perjanjian kredit adalah pengertian perjanjian pinjam mengganti sehingga apabila terdapat masalah sengketa perjanjian kredit dapat menggunakan dasar hukum perjanjian pinjam mengganti menurut KUHPerdata tersebut.

Perjanjian kredit termasuk ke dalam perjanjian innominat (Salim, 2005) sehingga ketentuannya tidak secara khusus diatur dalam KUHPerdata. Namun para sarjana hukum memiliki pendapat yang berbeda tentang hal ini yang secara garis besar, pendapat para sarjana hukum mengenai pengaturan perjanjian kredit dapat dibagi menjadi dua, yaitu bahwa perjanjian kredit pengaturannya merujuk pada Buku III KUHPerdata dan perjanjian kredit pengaturannya tunduk kepada Undang-Undang Perbankan.

Subjek perjanjian kredit adalah pihak kreditor yang berhak atas prestasi dan pihak debitor yang berkewajiban atas prestasi (Harahap, 1986). Hal ini senada dengan apa yang diatur di dalam Pasal 1234 KUHPerdata, bahwa prestasi dapat berbentuk memberikan sesuatu, berbuat sesuatu, atau tidak berbuat sesuatu.

Kredit dalam arti lain juga bermakna penyediaan uang atau tagihan yang dapat disamakan dengan itu, berdasarkan persetujuan pinjam-meminjam antara bank dengan pihak lain yang mewajibkan pihak pinjaman untuk melunasi utangnya setelah jangka waktu dengan jumlah bunga, imbalan atau pembagian hasil keuntungan (Hay, 1975).
Terkait mengenai perjanjian kredit tersebut, maka penulis akan mendeskripsikan perjanjian kredit yang ada di dalam Perbankan Konvensional dari beberapa aspek, di antaranya adalah: Asas Perjanjian Kredit, Bentuk dan Isi Perjanjian Kredit, Sifat Hukum Perjanjian Kredit, Ketentuan Syarat Perjanjian Kredit, dan Fungsi Jaminan Kredit dalam Perbankan Konvensional.

\section{Asas Perjanjian Kredit}

$\begin{array}{rrrr}\text { Di } & \text { dalam } & \text { Perjanjian } & \text { Kredit } \\ \text { dikenal yang } & \text { namanya } & \text { Asas }\end{array}$

Kesetaraan, sebagaimana yang dimaknai dalam bahasa sehari-hari, bahwa kata seimbang (evenwicht) menunjuk pada pengertian suatu keadaan pembagian beban di kedua sisi benda dalam keadaan seimbang (Budiono, 2006).

Bahwa perjanjian adalah suatu proses yang bermula dari suatu janji menuju kesepakatan (bebas) dari para pihak dan berakhir dengan pencapaian tujuan yaitu perjanjian yang tercapai dalam semangat atau jiwa keseimbangan. Dalam lingkup suasana hukum Indonesia tujuan dari kontrak yakni tercapainya kapatutan sosial (sociale gezindheid) dan suatu keseimbangan selaras (kemungkinan eksistensi materiil (immateriele zijnsmogelijkheid). Perjanjian yang dari sudut substansi atau maksud dan tujuannya ternyata bertentangan dengan kesusilaan atau ketertiban umum batal demi hukum (nietig) dan pada prinsipnya hal serupa akan berlaku berkenaan dengan perjanjian yang bertentangan dengan undangundang.

Asas keseimbangan dilandaskan pada upaya mencapai suatu keadaan seimbang yang sebagai akibat darinya harus munculkan pengalihan kekayaan secara absah. Tidak 
terpenuhinya keseimbangan, dalam konteks asas keseimbangan, bukan semata menegaskan fakta dan keadaan, melainkan lebih dari itu berpengaruh terhadap kekuatan yuridikal perjanjian dimaksud. Dalam tercipta atau terentuknya perjanjian, ketidakseimbangan bisa muncul sebagai akibat perilaku para pihak sendiri ataupun sebagai konsekwensi dari substansi (muatan isi) perjanjian atau pelaksanaan perjanjian..

Namun menurut Ridwan Khairandy, kebebasan berkontrak dan asas pacta sunt servanda dalam kenyataannya dapat menimbulkan ketidakadilan. Kebebasan berkontrak didasarkan pada asumsi bahwa para pihak dalam kontrak memiliki posisi tawar (bargaining position) yang seimbang, tetapi dalam kenyataannya para pihak tidak selalu memiliki posisi tawar yang seimbang. Akibatnya, pihak yang memiliki posisi tawar yang lebih kuat cenderung menguasai pihak yang memiliki posisi tawar yang lebih lemah (Khairandy, 2004).

Selain itu, Di dalam hukum perbankan konvensional, perjanjian menganut sistem terbuka (Subekti, 1991) yang mengandung asas kebebasan membuat perjanjian. Dikatakan bahwa Hukum Benda mempunyai sistem tertutup, sedangkan Hukum Perjanjian mengaanut sistem terbuka. Artinya macam-macam hak atas benda adalah terbatas dan peraturan-peraturan yang mengenai hak-hak atas benda itu bersifat memaksa, sedangkan Hukum Perjanjian memberikan kebebasan yang seluas-luasnya kepada masyarakat untuk mengadakan perjanjian yang berisi apa saja, asalkan tidak melanggar ketertiban umum dan kesusilaan. Di dalam KUHPerdata lazimnya disimpulkan dalam Pasal 1338 ayat (1), yang berbunyi demikian:

"Semua perjanjian yang dibuat secara sah berlaku sebagai undang-undang bagi mereka yang membuatnya".

Dengan menekankan pada perkataan Semua, maka pasal tersebut seolah-olah berisikan suatu pernyataan kepada masyarakat bahwa diperbolehkan membuat perjanjian yang berupa dan berisi apa saja (atau tentang apa saja) dan perjanjian itu akan mengikat mereka yang membuatnya seperti suatu undang-undang atau dengan kata lain, dalam soal perjanjian, kita diperbolehkan membuat undangundang atau aturan sendiri dimana pasal-pasal dari Hukum Perjanjian baru akan berlaku apabila di dalam perjanjian yang dibuat tidak terdapat aturan-aturan sendiri dalam perjanjian-perjanjian yang dibuat.

\section{Bentuk dan Materi (Isi) Perjanjian Kredit}

Sesuai yang tercantum dalam Pasal 1320 KUHPerdata mengenai syarat-syarat terjadinya suatu persetujuan yang sah dalam perjanjian kredit serta pemberian kredit oleh Bank kepada debitornya harus dalam bentuk perjanjian yang diberi nama Perjanjian Kredit hal ini sesuai dengan surat Bank Indonesia kepada segenap Bank Devisa No. 03/1093/OPK/KPD tanggal 29 Desember 1970. Perjanjian kredit juga harus dibuat secara tertulis yakni untuk kepentingan administrasi yang rapi dan teratur serta untuk kepentingan pembuktian.

Dalam praktek perbankan yang secara Yuridis ada 2 (dua) bentuk perjanjian kredit, yaitu: 
(1) Perjanjian kredit yang dibuat di bawah tangan atau akta di bawah tangan artinya perjanjian pemberian kredit oleh bank kepada nasabahnya yang dibuat hanya di antara mereka (kreditur dan debitur) tanpa Notaris. Lazimnya dalam penandatanganan akta perjanjian kredit, saksi turut serta membubuhkan tandatangannya karena saksi merupakan salah satu alat pembuktian dalam perkara perdata.

(2) Perjanjian kredit yang dibuat oleh dan di hadapan Notaris (notariil) atau akta otentik artinya perjanjian pemberian kreditoleh bank kepada nasabahnya yang hanya dibuat oleh atau di hadapan Notaris. Adapun akte otentik adalah suatu akte undangundang, dibuat oleh atau di hadapan pegawai-pegawai umum yang berkuasa untuk itu di tempat mana akte dibuat. Biasanya pemberian kredit dalam jumlah besar dengan jangka waktu menengah atau panjang. Contohnya kredit investasi, kredit modal kerja, dan kredit sindikasi.

Dalam praktiknya, bentuk dan materi (isi) perjanjian kredit antara satu bank dengan bank yang adalah berbeda. Ketidak samaan dalam perjanjian kredit tersebut karena ketidak samaannya pula dalam kebutuhan masing-masing pihak.

Maka dari pada itu, perjanjian kredit tidak ada bentuk yang berlaku umum. Hanya saja, menurut Muhammad Djumhana dalam praktik ada bebeberapa klausula yang biasa dicantumkan dalam perjanjiuan kredit, di antaranya mengenai: (Djumhana, 2006)

Syarat-syarat Penarikan Kredit Pertama kali (Predisbuursement Clause). Klausula ini menyangkut pembayaran provisi, premi asuransi kredit, dan asuransi barang jaminan, biaya pengikatan jaminan secara tunai, serta dokumennya. Mengenai pelaksanaan penutupan asuransi barang jaminan juga diatur dalam klausula ini yang tujuannyauntuk memperkecil resiko yang terjadi di luar kesalahan debitor maupun kreditor.

Maksimum Kredit. Klausula ini menjelaskan tentang obyek dari perjanjian kredit yang mana jika terjadi perubahan mengenai kredit yang diberikan maka konsekuensi hukumnya adalah diperlukannya perbuatan perjanjian kredit yang baru atau dibuatkan addendum terhadap perjanjian pokoknya. Klausula ini digunakan sebagai penetapan bersarnya nilai agunan yang harus diserahkan debitor. Dan yang terakhir adalah jangka waktu kredit itu sendiri yang termasuk dalam klausula transaksi perjanjian kredit.

\section{Sifat Hukum Perjanjian Kredit}

Di dalam literatur terdapat beberapa pendirian mengenai sifat hukum perjanjian kredit yang secara garis besar dapat digolongkan ke dalam tiga kelompok, yaitu perjanjian kredit yang bersifat riil, perjanjian kredit bersifat konsensual, dan perjanjian kredit bersifat konsensual dan riil. Masing-masing pendirian memiliki argumen, dasar hukum dan justifikasinya tersendiri.

Perjanjian Kredit yang bersifat Riil. Riil berarti bahwa perjanjian baru ada setelah uang yang dipinjamkan dalam perjanjian kredit diserahkan secara nyata kepada debitur. Di dalam KUHPerdata mengatur perjanjian pinjammeminjam yaitu satu pihak menyerahkan kepada pihak lain sejumlah uang atau barang-barang 
yang dapat diganti dengan janji pihak lain untuk di kemudian hari mengembalikan kepada pihak kesatu sejumlah uang yang sama atau sejumlah barang-barang yang sama jenis dan nilainya.

Wirjono Prodjodikoro menyatakan bahwa perjanjian pinjam uang bersifat riil, tersimpul dari kalimat "pihak kesatu menyerahkan uang itu kepada pihak lain" dan bukan "mengikatkan" diri untuk menyerahkan uang (Prodjodikoro, 1981). Pendapat tersebut mendukung bahwa pinjam-meminjam uang adalah sifat hukum dari perjanjian kredit yang bersifat riil artinya perjanjian yang baru tercipta dengan diserahkannya barang-barang (uang) yang menjadi obyek perjanjian.

Perjanjian Kredit yang bersifat Konsensual adalah perjanjian yang terjadi sejak adanya kesepakatan. Dilihat dari perjanjian kredit dan perjanjian pinjam uang adalah merupakan suatu perjanjian yang menentukan sifat hukum perjanjian kredit yaitu konsensual (pactum de contranendo) dan obligatoir (suatu perjanjian di mana mengharuskan atau mewajibkan seseorang membayar atau menyerahkan sesuatu). Dasar dari kekuatan mengikat adalah Pasal 1338 KUHPerdata yang dikutip dari buku perjanjian kredit bank karangan Mariam Darus Badrulzaman, Windscheid mengemukakan bahwa perjanjian kredit adalah perjanjian dengan syarat tangguh (condition ptestative), yang pemenuhannya tergantung pada peminjam. Dasar hukumnya adalah Pasal 1253 KUHPerdata, suatu perikatan adalah bersyarat manakala ia digantungkan pada suatu peristiwa yang masih akan datang dan yang masih belum tentu akan terjadi, baik secara menangguhkan perikatan sehingga terjadinya peristiwa semacam itu, maupun secara membatalkan perikatan menurut terjadi atau tidaknya peristiwa tersebut (Badrulzaman, 1991).

Perjanjian Kredit bersifat Konsensual dan Riil. Sifat konsensual dan riil yang terdapat dalam perjanjian kredit adalah sebagai perpaduan antara pendapat bahwa perjanjian kredit bersifat konsensual dan riil. Artinya diposisikan ada dua perjanjian yang berdampingan, yaitu yang pertama adalah perjanjian untuk mengadakan perjanjian pinjaman mengganti dimana perjanjian ini adalah timbal balik yang satu wajib menyerahkan benda (uang) yang dipinjamkan, sedangkan pihak yang lain wajib menerima benda (uang) itu dan yang kedua adalah perjanjian pinjam menggganti yaitu perjanjian sepihak, bernama, yang diatur di dalam Pasal 1754Pasal 1759 KUHPerdata.

F. Van Der Feltz dalam bukunya De Overeenkomst van Verbuiklening menyatakan bahwa perjanjian pinjam mengganti baru terjadi setelah ada penyerahan (overgave), selama benda (uang) yang dipinjamkan belum diserahkan maka Bab XIII Buku III KUHPerdata belum dapat diterapkan. Apabila dua pihak bersepakat tentang semua unsur-unsur dalam perjanjian pinjam mengganti, maka tidak berarti bahwa perjanjian pinjam mengganti itu telah terjadi. Yang terjadi sesungguhnya adalah perjanjian untuk mengadakan perjanjian pinjam mengganti. Apabila uang diserahkan kepada pihak meminjam, maka lahirlah perjanjian pinjam mengganti dalam pengertian Bab XIII Buku III KUHPerdata. 


\section{Syarat Perjanjian Kredit}

Dalam Pasal 1320 KUHPerdata untuk sahnya suatu perjanjian diperlukan empat syarat yaitu; (1) sepakat mereka yang mengikatkan dirinya; (2) cakap untuk membuat suatu perjanjian; (3) mengenai suatu hal tertentu; dan (4) suatu sebab yang halal.

Menurut Subekti, dua syarat yang pertama dinamakan syaratsyarat subyektif, karena mengenai orang-orangnya atau subyek dari yang mengadakan perjanjian, sedangkan dua syarat yang terakhir dinamakan syarat-syarat obyektif karena mengenai perjanjiannya sendiri atau obyek dari perbuatan hukum yang dilakukan itu (Subekti, 1991).

Menurut S.B. Marsh dan J. Soulsby, dalam pelaksanaan suatu perjanjian sebelum perjanjian dibuat yang ditinjau dari syarat pelaksanaan suatu perjanjian, pemberian pinjaman harus memberikan keterangan tertentu kepada peminjam dengan cara yang ditetapkan. Peraturan-peraturan yang meliputi ini mungkin akan memerlukan pemberitahuan secara tertulis tentang harga tunai dan harga kredit. Perjanjian itu sendiri harus memenuhi syarat-syarat sebagai berikut:

(1) Perjanjian itu harus tertulis, ditandatangai oleh debitor secara pribadi dan oleh atau atas nama kreditor. Tanda tangan dalam dalam bentuk blanko, meninggalkannya pada seorang levelansir atau agen untuk diisi secara terinci, tidaklah cukup.

(2) Dokumen itu harus dalam bentuk yang ditetapkan, dan berisi (dalam beberapa hal badan hukum dengan referensi) keterangan yang ditentukan, terutama hak dan kewajiban debitor, perlindungan dan upaya hukum yang tersedia baginya menurut undang-undang, dan jumlah kredit dan jumlah biaya keseluruhan untuk kredit itu.

(3) Pemberitahuan tentang hakhak pembatalan harus diberikan dalam semua perjanjian yang dapat dibatalkan.

Selain dari perjanjian itu harus diberikan kepada debitor, ia harus selalu menerima dengan segera satu copy dari formulir yang di tandatangani. Jika kemudian formulir itu harus dikirimkan untuk diselesaikan oleh kreditor, debitor juga harus diberi copy dari perjanjian yang sudah diselesaikan itu dalam tujuh hari sejak penyelesaiannya, sehingga ia dapat memeriksa bahwa tidak ada pergantian yang telah dilakukan sejak penandatangannya. Dalam hal perjanjian yang dapat dibatalkan, copy kedua ini harus dikirimkan dengan pos dan berisi rincian tentang hak-hak debitor untuk membatalkan.

\section{Fungsi Jaminan Kredit}

Menurut Subekti (1999) bahwa jaminan yang ideal yang bisa digunakan dalam kredit perbankan yaitu: (1.) dapat secara mudah membantu perolehan kredit oleh pihak yang membutuhkannya; (2.) tidak melemahkan posisi (kekuatan) si penerima kredit untuk meneruskan usahanya; (3.) memberikan kepastian kepada kreditor dalam arti bahwa yaitu apabila perlu, mudah diuangkan untuk melunasi utang si debitor.

Pemberian kredit sama halnya dengan salah satu bentuk pinjaman uang. Dalam hal pemberian kredit perbankan, mengenai jaminan utang disebut dengan sebutan jaminan kredit atau agunan. Jaminan kredit 
umumnya dipersyaratkan dalam suatu pemberian kredit.

Sehubung dengan adanya persyaratan yang mewajibkan (calon) debitor untuk menyerahkan (memberikan) jaminan kredit, maka hal tersebut lebih berkaitan dengan beberapa fungsinya. Mengenai fungsi jaminan kredit baik ditinjau dari sisi bank sebagai kreditor maupun dari sisi debitor dapat dikemukakan lebih lanjut sebagai berikut.

Pertama, jaminan kredit sebagai pengamanan pelunasan kredit. Fungsi ini baru akan muncul pada saat kredit dinyatakan sebagai kredit macet. Selama kredit telah dilunasi oleh debitor, tidak akan terjadi pencairan jaminan kreditnya. Dalam hal ini jaminan kredit akan dikembalikan kepada debitor yang bersangkutan sesuai dengan ketentuan hukum dan perjanjian kredit.

Jaminan kredit berfungsi untuk mengamankan pelunasan kredit sangat berkaitan dengan kepentingan bank yang menyalurkan dananya kepada debitor yang sering dikatakan mengandung resiko. Jika debitor ingkar janji maka dengan adanya jaminan kredit tersebut yang telah diikat bank secara hukum yang berlaku, fungsi tersebut akan terlaksana.

Kedua, sebagai pendorong motivasi debitor. Umumnya sesuai dengan ketentuan intern masingmasing bank, nilai jaminan kredit yang diserahkan debitor kepada bank lebih besar bila dibandingkan dengan nilai kredit yang diberikan bank kepada debitor yang bersangkutan. Hal inilah yang memberikan motivasi kepada debitor untuk menggunakan kredit sebaik-baiknya, melakukan kegiatan usahanya secara baik, mengelola kondisi keuangan secara hati-hati sehingga dapat segera melunasi kreditnya agar dapat menguasai kembali hartanya. Tidak dapat dipungkiri siapapun juga pasti tidak ingin kehilangan harta (aset)nya karena merupakan sesuatu yang dibutuhkan, mempunyai nilai-nilai tertentu atau disayangi.

Ketiga, fungsi yang terkait dengan pelaksanaan ketentuan perbankan. Keterkaitan dengan ketentuan-ketentuan dari berbagai peraturan perundang-undangan tentang perbankan seperti yang tersebut di atas merupakan fungsi lain dari jaminan kredit dan mendukung keharusan penilaian jaminan kredit secara lengkap oleh bank sehingga akan merupakan jaminan yang layak dan berharga.

\section{Akad Pembiayaan Dalam Perbankan Syariah}

Sebagaimana dijelaskan dalam Undang-Undang Perbankan Syariah yang menerangkan pengertian Pembiayaan adalah penyediaan dana atau tagihan yang dipersamakan dengan itu berupa: termasuk di dalamnya mengenai transaksi bagi hasil, transaksi sewa-menyewa, trasaksi jual beli dalam bentuk piutang, transaksi pinjam meminjam dan transaksi sewa-menyewa jasa dalam bentuk ijarah untuk transaksi multijasa berdasarkan persetujuan atau kesepakatan antara bank syariah dan atau Unit Usaha Syariah (UUS) dan pihak lain yang mewajibkan pihak yang dibiayai dan atau diberi fasilitas dana untuk mengembalikan dana tersebut setelah jangka waktu tertentu dengan imbalan ujrah, tanpa imbalan, atau bagi hasil.

Sistem yang dianut dalam perbankan syariah adalah sistem pembiayaan yang berbeda dengan sistem kredit yang dianut dalam 
perbankan konvensional. Perbankan syariah dengan sistem bagi untung dan rugi (Profit and Loss Sharing) memiliki konsep yang dianggap sangat tepat di tengah kondisi ketidakadilan yang dialami oleh masyarakat. Konsep kebersamaan dalam menghadapi risiko dan memperoleh keuntungan, serta adanya keadilan dalam berusaha menjadi suatu potensi yang sangat strategis bagi perkembangan Bank Syariah di masa yang akan datang. Hal ini disebabkan oleh sebahagian besar atau mayoritas penduduk Indonesia adalah beragama Islam, tantangan ini sekaligus menjadi prospek yang cukup cerah untuk pengembangan Bank Syariah di Masyarakat. Di samping itu bank syariah dengan sistem bagi hasil yang lebih mengutamakan stabilitas di atas rentabilitas (Sood; 2005).

Dalam penyaluran dana atau pembiayaan menggunakan metode bagi hasil yang disepakati bersama antara pihak bank dan nasabah, penyaluran dananya pun harus sesuai dengan yang difatwakan oleh Dewan Syariah Nasional Majelis Ulama Indonesia (DSN-MUI).

Proporsi bagi hasil didasarkan atas jumlah keuntungan usaha yang diperoleh nasabah. Pada bank syariah tidak menentukan keuntungan pasti yang diterapkan di awal perjanjian, namun keuntungan di muka hanya dimungkinkan untuk akad-akad jual beli melalui kredit kepemilikan barang atau aktiva. Sebagaimana yang diungkapkan Karnaen dan Antonio yang mana fasilitas kredit kebajikan yang tidak membebani nasabah dengan biaya apa pun kecuali biaya yang dipergunakannya sendiri (Antonio, 1992).
Menurut Fathurrahman Djamil bahwa di dalam ajaran Islam untuk sahnya suatu akad, harus dipenuhi rukun dan syarat dari suatu akad. Rukun adalah unsur yang mutlak harus dipenuhi dalam sesuatu hal, peristiwa dan tindakan. Sedangkan syarat adalah unsur yang harus ada untuk sesuatu hal, peristiwa, dan tindakan tersebut.

Rukun akad yang utama adalah ijab dan kabul. Syarat yang harus ada dalam rukun bisa menyangkut subyek dan obyek dari suatu akad. Sedangkan syarat dalam akad termasuk dalam akad pembiayaan akan dibahas selanjutnya dengan beberapa hal yang terkait dalam akad pembiayaan dalam perbankan syariah, Baik itu asas, bentuk, sifatsifat, ketentuan syarat serta jaminan akad pembiayaan dalam perbankan syariah.

\section{Asas-Asas Akad Pembiayaan}

Sebagaimana dalam hukum perjanjian menurut KUHPerdata yang mengenal beberapa asas, di dalam hukum Islam juga mengenal asas-asas hukum akad (perjanjian) yang kesemua ini tidak lepas dengan asas yang telah diatur di dalam UndangUndang Perbankan Syariah dalam melakukan kegiatan usahanya yang berasaskan prinsip syariah, demokrasi ekonomi, dan prinsip kehati-hatian dalam mengelola sistem dalam perbankan syariah. Namun jika secara spesifik mengenai asas dalam akad pembiayaan maka menurut Fathurrahman Djamil, dia membaginya dalam beberapa bagian yaitu sebagai berikut: (Djamil, 2001)

(1.) Al-Hurriyah (Kebebasan) adalah suatu asas yang merupakan prinsip dasar dalam hukum perjanjian Islam, dalam artian para pihak bebas membuat suatu 
perjanjian atau akad (freedom of making contract) yaitu di dalam hukum Islam asas ini dibatasi oleh ketentuan dalam syariah (hukum Islam), sehingga dalam membuat perjanjian ini tidak boleh ada unsur paksaan, kekhilafan, dan penipuan.

(2.) Al-Musawwah (Persamaan atau Kesetaraan) yaitu di mana asas ini mengandung pengertian bahwa para pihak mempunyai kedudukan (bargaining position) yang sama, sehingga dalam menentukan term and condition dari suatu akad setiap pihak mempunyai kesetaraan atau kedudukan yang seimbang.

(3.) Al-'Adalah (Keadilan) yaitu dimana pelaksanaan asas ini dalam suatu akad menuntut para pihak untuk melakukan yang benar dalam pengungkapan kehendak dan keadaan, memenuhi semua kewajibannya. Perjanjian harus senantiasa mendatangkan keuntungan yang adil dan seimbang, serta tidak boleh mendatangkan kerugian bagi salah satu pihak.

(4.) Al-Ridha (Kerelaan) yaitu asas yang menyatakan bahwa segala transaksi yang dilakukan harus atas dasar kerelaan antara masing-masing pihak, harus didasarkan pada kesepakatan bebas dari para pihak dan tidak boleh ada unsur paksaan, tekanan, penipuan, dan misstatement.

(5.) Ash-Shidq (Kebenaran dan Kejujuran) yaitu asas yang melarang untuk setiap orang untuk melakukan kebohongan sebagaimana aturan di dalam Islam. Karena dengan adanya kebohongan (penipuan) sangat berpengaruh dalam keabsahan akad. Akad yang di dalamnya ada kebohongan maka akan memberikan hak kepada pihak lain untuk menghentikan proses pelaksanaan akad tersebut.

(6.) Al-Kitabah (tertulis) yaitu asas yang menyatakan bahwa setiap perjanjian hendaknya dibuat secara tertulis, lebih berkaitan demi kepentingan pembuktian jika di kemudian hari terjadi sengketa dan hal tersebut bisa menjadi akta otentik.

\section{Bentuk Akad Pembiayaan}

Layaknya bentuk perjanjian kredit dalam perbankan konvensional, di dalam perbankan syariah juga terdapat pengklasifikasian bentuk akad pembiayaan, sebagaimana yang dijelaskan oleh Abdul Ghofur Anshori, yaitu (Anshori, 2006): (1.) akad tidak tertulis, yaitu akad yang dibuat secara lisan saja dan biasanya terjadi pada akad yang sederhana, misalnya: jual beli kebutuhan komsumsi sehari-hari; (2.) akad tertulis, yaitu akad yang dituangkan dalam bentuk tulisan/akta baik akta otentik maupun akta bawah tangan. Akad yang dibuat secara tertulis biasanya untuk akad-akad yang komplek atau menyangkut kepentingan publik, misalnya akad wakaf, akad jual beli ekspor impor, dan sebagainya.

Untuk saat ini, secara umum yang digunakan dalam sistem perbankan syariah yang masuk dalam sektor ialah akad tertulis. Adapun akad tersebut terbagi di dalam dua bentuk, yaitu: (1.) Akad Tabarru adalah jenis akad yang berkaitan dengan transaksi nonprofit (transaksi) yang tidak bertujuan semata-mata untuk mendapatkan laba atau keuntungan; (2.) Akad Tijarah (akad mu'amalah) adalah akad yang bertujuan untuk mendapatkan imbalan berupa keuntungan tertentu. Atau dengan 
kata lain akad ini menyangkut transaksi bisnis dengan motif untuk memperoleh laba (profit oriented).

\section{Sifat-Sifat Akad Pembiayaan}

Di lihat dari sifat-sifat akad pembiayaan, salah satunya adalah sifat mengikat yaitu terdiri dari: (1.) akad yang mengikat secara pasti, artinya tidak boleh di fasakh (dibatalkan secara sepihak); (2.) akad yang tidak mengikat secara pasti, yaitu akad yang dapat difasakh oleh dua pihak atau oleh satu pihak.

\section{Ketentuan Syarat \\ Akad Pembiayaan}

Menurut Ahmad Azhar Basyir, terdapat beberapa ketentuan syaratsyarat yang harus dipenuhi agar kesepakatan para pihak (ijab kabul) mempunyai akibat hukum, yaitu (Basyir, 2000) : (1.) ijab dan kabul harus dinyatakan oleh orang yang sekurang-kurangnya telah mencapai umur tamyiz yang menyadari dan mengetahui isi perkataan yang diucapkan hingga ucapannya itu benar-benar menyatakan keingainan hatinya. Dengan kata lain dilakukan oleh orang yang cakap melakukan tindakan hukum; (2.) ijab dan kabul harus tertuju pada suatu obyek yang merupakan obyek perjanjian; dan (3.) ijab dan kabul haru berhubungan langsung dalam suatu majelis apabila dua belah pihak sama-sama hadir.

Selain itu, jumhur ulama mengatakan bahwa ijab dan kabul merupakan salah satu unsur penting dalam suatu perjanjian/akad, di samping unsur-unsur lain yang juga termasuk rukun akad. Unsur-unsur tersebut terdiri dari: (1.) Shighat alaqad (pernyataan untuk mengikatkan diri), adalah cara bagaimana pernyataan pengikatan diri dilakukan dimana para pihak harus menyampaikannya secara lisan/ tertulis term and condition dari dari akad tersebut agar dapat menimbulkan akibat hukum; (2.) alMa'qud alaih/mahal al-'aqad (obyek akad), objek dari akad atau perjanjian harus memenuhi persyaratan berupa telah ada pada waktu akad diadakan; (3.) alMuta'aqidain/al-'aqadain (pihakpihak yang berakad), adalah pihak yang sama-sama mempunyai kecakapan melakukan tindakan hukum dalam artian sudah dewasa dan sehat akal dan pikirannya; dan (3.) Maudhu' al-'aqd (tujuan akad), menurut ulama fiqh bahwa tujuan akad adalah harus sejalan dengan kehendak syarak maka berakibat pada ketidak absahan dari perjanjian yang dibuat. Tujuan harus ada pada saat akad diadakan, dapat berlangsung hingga berakhirnya akad, dan harus dibenarkan oleh syarak.

Dari penjelasan tersebut di atas, maka akan disimpulkan bahwa terdapat beberapa syarat yang harus terdapat dalam akad, namun dapat dibagi menjadi dua macam, yaitu:

Pertama, syarat umum, yaitu syarat-syarat yang wajib sempurna wujudnya dalam segala macam akad.

Kedua, syarat khusus, yaitu syarat-syarat yang diisyaratkan wujudnya dalam sebagian akad, tidak dalam pembagian yang lain. Syaratsyarat ini juga biasa disebut sebagai syarat tambahan (syarat idhafiyah) yang harus ada di samping syaratsyarat umum, seperti adanya saksi untuk terjadinya nikah.

Sehingga disimpulkan beberapa syarat yang harus terdapat dalam segala macam akad dalam pembiayaan perbankan syariah yang senada dengan pendapat yang sudah dijelaskan sebelumnya, syarat-syarat 
tersebut adalah: (1.) Ahliyatul'aqidaini (kedua pihak yang melakukan akad cakap bertindak atau ahli); (2.) Qabiliyatul mahalli aqdi li hukmihi (yang dijadikan objek akad dapat menerima hukuman); (3.) Alwilyatus syar'iyah fi maudhu'il aqdi (akad itu diizinkan oleh syara dilakukan olen orang yang mempunyai hak melakukannya dan melaksanakannya, walaupun dia bukan si 'aqid sendiri); (4.) Alla yakunal 'aqdu au madhu'uhu mamnu'an binashshin syar'iyin (janganlah akad itu yang dilarang syara) seperti bai' munabadzah.; (5.) kaunul 'aqdi mufidan (akad itu memberikan faedah); (6.) Baqaul ijabi shalihan ila mauqu'il qabul (ijab berjalan terus, tidak dicabut, sebelum terjadi qabul); (7.) Ittihadu majalisil 'aqdi (bertemu di majelis akad). Maka ijab menjadi batal apabila berpisah salah seorang dari yang lain dan belum terjadi qabul (Firdaus $\mathrm{NH}$, et.al., 2005).

Jaminan Pembiayaan (Profit and Loss Sharing)

Jaminan merupakan suatu kepercayaan yang diberikan peminjam (mudharib) kepada pemberi pinjaman, bahwa ia tidak akan wanprestasi terhadap yang diperjanjikannya dan kepercayaan tersebut diaktualisasikan dalam bentuk jaminan. Aktualisasi jaminan dalam pembiayaan mudharbah contohnya merupakan upaya bank syariah dalam mengantisipasi kerugian yang akan terjadi. Bank syariah tidak begitu saja menyalurkan pembiayaan kepada mudharib atas dasar kepercayaan, karena selalu ada risiko antara lain pembiayaan yang telah diberikan kepada mudharib tidak dipergunakan sebagaimana mestinya begitu dan dikelola oleh mudharib, maka akses informasi bank terhadap usaha mudharib menjadi terbatas. Dengan demikian terjadi ketidak samaan informasi (assymetic information) dimana mudharib banyak mengetahui informasi yang tidak diketahui oleh bank. Hal ini memungkinkan adanya perilaku yang tidak peduli pada resiko (moral hazard) oleh mudharib, yakni mudharib melakukan hal-hal yang menguntungkan mudharib tapi merugikan shahibul mal (bank).

Untuk menghindari risiko tersebut, maka bank syariah menerapkan batasan-batasan yang dikenal incentive compatible constraints yaitu mudharib secara sistematis dipaksa untuk berperilaku memaksimalkan keuntungan bagi kedua belah pihak, baik mudharib sendiri maupun shohibul maal (Karim, 2001).

Syarat dan ketentuan jaminan merupakan syarat mutlak dalam pemberian pembiayaan merupakan pengaman bagi bank dalam mengantisipasi kerugian pada keadaan tertentu supaya kerugian bank dapat dihindari.

Pada umumnya jaminan yang digunakan dalam pembiayaan profit and loss sharing adalah jaminan kebendaan, karena jaminan kebendaan memiliki keterkaitan langsung dengan nasabah pembiayaan. Jika nasabah pembiayaan tidak dapat membayar kewajibannya, maka akan memudahkan bank untuk melakukan proses pemenuhan kewajiban nasabah pembiayaan (Imaniyati, 2013).

\section{Simpulan}


Dari pembahasan di atas maka didapatkan kesimpulan bahwa:

a. Melakukan perjanjian kredit adalah suatu proses awal antara kreditor dan debitor yang diterapkan dalam sistem perbankan konvensional dalam upayanya untuk mengembangkan dana yang telah dihimpunnya dan juga untuk dimanfaatkan dananya dengan sebaik-baiknya. Menurut asasnya perjanjian menganut sistem terbuka yang mengandung asas kebebasan membuat perjanjian, dan menurut bentuknya perjanjian kredit dalam perbankan konvensional ada yang dibuat di bawah tangan dan ada pula dibuat di hadapan notaris.

b. Di dalam akad pembiayaan perbankan syariah menganut sistem bagi untung dan rugi (Profit and Loss Sharing) yang diyakini memiliki konsep yang dianggap sangat tepat di tengah kondisi ketidakadilan yang dialami oleh masyarakat. Konsep kebersamaan dalam menghadapi risiko dan memperoleh keuntungan, serta adanya keadilan dalam berusaha menjadi suatu potensi yang sangat strategis bagi perkembangan Bank Syariah di masa yang akan datang. Sedangkan akad dalam pembiayaan yang ada dalam perbankan syariah hampir memiliki prinsip yang sama

\section{Daftar Pustaka}

\section{Buku/Makalah/Jurnal}

Anshori, Abdul Ghofur, 2006, PokokPokok Hukum Perjanjian Islam di Indonesia, Citra Media, Yogyakarta. dengan perbankan konvensional dalam penerapannya.

\section{Saran}

Baik pemberian pinjaman uang melalui kredit yang dianut dalam sistem perbankan konvensional maupun pemberian pembiayaan yang dianut dalam sistem perbankan syariah kepada debitor dan mudharib sejatinya adalah bertujuan satu yaitu untuk membantu mensejahterahkan masyarakat secara adil dan merata.

Sistem kontrol yang tinggi dan aktif oleh pemerintah melalui Bank Indonesia dan Otoritas Jasa Keuangan yang didukung dengan regulasi yang tegas terhadap lembaga perbankan harus dimaksimalkan agar pemberian kredit dan pembiayaan bisa dipermudah kepada debitor dan mudharib untuk tujuan kesejahteraan masyarakat.

Dalam hal ini lembaga perbankan justru yang berperan aktif untuk mengontrol, mengawasi dan mengarahkan para nasabahnya untuk mencapai tujuan mereka. Bukan justru nasabah yang berperan aktif untuk mencari pinjaman dan pembiayaan sedangkan lembaga perbankan yang pasif dalam hal ini.

Sehingga pemberian kredit dan pembiayaan nantinya tidak selalu diperuntukkan orang yang mampu saja tapi diperuntukan bagi golongan menengah ke bawah, sehingga tercipta keadilan sosial dan ekonomi dalam masyarakat kita sebagaimana yang dicita-citakan oleh Pancasila sebagai ruh dari negara kita.

2007, Perbankan Syariah di Indonesia, Gadjah Mada University Press, Yogyakarta. Ash-Shiddiqy, M Hasbi, 2001, Pengantar Fiqh Muamalah, Putra Rizki Utama, Semarang. 
Azzam, Abdul Aziz Muhammad, 2010, Fiqh Muamalat: Sistem TransSaksi Dalam Fiqh Islam, Amzah, Jakarta.

Badrulzaman, Mariam Darus, 1991, Perjanjian Kredit Bank (beberapa Masalah Hukum Dalam Perjanjian Kredit Bank Dengan Jaminan Hypotheek Serta Hambatan-Hambatannya Dalah Praktek di Medan, Citra Aditya Bakti, Bandung.

Bahsan, M., 2007, Hukum Jaminan dan Jaminan Kredit Perbankan Indonesia, RajaGrafindo Persada, Jakarta.

Basyir, Ahmad Azhar, 2000, Asas-Asas Hukum Muamalat (Hukum Perdata Islam), UII Press, Yogyakarta.

Bix, Brian H., Theories of Contract law and Enforcing Promissory Morality: Comments on Charles Fried, Legal Studies Research Paper Series, Research Paper No. 11-47, University of Minnesota Law School.

Djamil, Fathurrahman, et. al., 2001, Hukum Perjanjian Syariah Dalam Kompilasi Hukum Perikatan, Citra Aditya Bakti, Bandung

Djumhana, Muhammad, 2006, Hukum Perbankan di Indonesia, Citra Aditya Bakti, Bandung.

Firdaus, Muhammad, et, al., 2005, Briefcase Book Edukasi Profesional Syariah, Cara Mudah Memahami Akad-Akad Syariah, Renaisan, Jakarta.

Fried, Charles, 1981, Contract as Promise Thirty Years On, Harvard.

Harahap, M. Yahya, 1986, Segi-segi Hukum Perjanjian, Alumni, Bandung.
Hay, Murhainis Abdul, 1975, Hukum Perbankan di Indonesia, Jilid II, Pradnya Paramita, Jakarta.

http://al-aziz-

imronrosadi.blogspot.com/201

3/07, Hukum Perjanjian dalam Perspektif Hukum Islam (Alqur'an dan Hadis), diambil pada tanggal 22/01/2015.

Ikatan Bankir Indonesia, 2014, Memahami Bisnis Bank (modul sertifikasi tingkat I general Banking), edisi ke-2, cet. Ke-2, Gramedia Pustaka Utama, Jakarta.

Imaniyati, Neni Sri, 2013, Perbankan Syariah dalam Perspektif Hukum Ekonomi, Mandar Maju, Bandung.

Karim, Adiwarman A, 2001, Ekonomi Islam: Suatu Kajian Kontemporer, Gema Insani Press, Jakarta.

Khairandy, Ridwan, 2004, Itikad Baik dalam Asas Kebebasan berkontrak, Program Pascasarjana Fakultas Hukum Universitas Islam Indonesia, Jakarta

Kuzari, Achmad, 1995, Nikah Sebagai Perikatan, Raja Grafindo Persada, Jakarta.

Marsh, S. B., dan J. Soulsby, 2013, Business Law, Hukum Perjanjian (terjemahan), Cet. Ke-4, Alumni, Bandung.

Marsh, S.B. dan J. Soulsby, 2013, Hukum Perjanjian, Cet. Ke-4, Alumni, Bandung.

NH, Muhammad Firdaus, et.al., 2005, Briefcase Book Edukasi Profesional Syariah, Cara Mudah Memahami Akad-Akad Syariah, Renaisan, Jakarta.

Perwataatmadja, Karnaen, dan Muhammad Syafi'i Antonio, 1992, Apa dan Bagaimana Bank 
Islam, Dana Bakti Wakaf, Yogyakarta.

Prodjodikoro, Wirjono, 1991, Hukum Perdata Tentang Persetujuanpersetujuan Tertentu, Sumur Bandung, Bandung.

Salim, 2005, Hukum Kontrak, Sinar Grafika, Jakarta.

Soekanto, Soejono, 2006, Pengenalan Penelitian Hukum, Grafindo, Jakarta.

Sood, M., et.al., 2005, Kedudukan dan Kewenangan Dewan Pengawas Syariah dalam Struktur PT. Bank berkaitan dengan UU No 1 Tahun 1995 tentang Perseroan terbatas dan Produk Fatwa Dewan Syariah Nasional, Laporan Penelitian, Kerja Sama Antara Bank Indonesia dengan Fakultas Hukum Universitas Mataram.

Subekti, 1991, Hukum Perjanjian, Cet. Ke XIII, Intermasa, Jakarta. 1991, Jaminan-Jaminan Untuk Pemberian Kredit Menurut Hukum Indonesia, Citra Aditya Bakti, Bandung.

Suhendi, Hendi, 2002, Fiqh Muamalah, Rajawali Press, Jakarta.

2007, Fiqh Mumalah: Membahas Ekonomi Islam Kedudukan Harta, Hak Milik, Jual Beli, Bunga Bank dan Riba, Musyarakah, Ijarah, Mudayanah, Koperasi, Asuransi, Etika Bisnis dan lain-lain, cet. V, PT. RajaGrafindo Persada, Jakarta.

Sumiyanto, Ahmad, 2005, Problem dan Solusi Transaksi Mudharabah di Lembaga Keuangan Mikro Syari'ah BMT, Magistra Insani Press, Yogyakarta.
Tim Prima Pena, 2006, Kamus Ilmiah Populer Edisi Lengkap, Gita Media Press, Surabaya.

Triandaru, Sigit, dan Totok Budisantoso, 2006, Bank dan Lembaga Keuangan Lain, Salemba Empat, Jakarta.

Tutik, Titik Triwulan, 2008, Hukum Perdata Dalam Sistem Hukum Nasional, Kencana, Jakarta.

Wibowo, Edy dan Untung Hendy, 2005, Mengapa Memilih Bank Syariah, Ghalia Indonesia, Jakarta.

\section{Undang-Undang}

Kitab Undang-Undang Hukum Perdata/ Burgerlijk Wetboek

Undang-Undang Nomor 21 Tahun 2008 Tentang Perbankan Syariah.

Undang-Undang Nomor 10 Tahun 1998 Tentang Perubahan Atas Undang-Undang Nomor 7 Tahun 1992 Tentang Perbankan Undang-Undang Nomor 7 Tahun 1992 tentang Perbankan sebagaimana telah diubah dengan Undang-undang Nomor 10 Tahun 1998.

\section{Lain-Lain}

Al-Qur'an

Yunus, Mahmud, 1990, Kamus ArabIndonesia, Hidakarya Agung, Jakarta. 